\title{
The Relationship between Telegram Application as a History Learning Platform and Student Performance
}

\author{
Tuan Shariffah Khairiah Tuan Kechil ${ }^{1}$, Mohd Mahzan bin Awang ${ }^{2}$ \& Abdul Razaq \\ bin Ahmad $^{3}$ \\ ${ }^{1}$ Kolej Al-Quran Terengganu, Malaysia \\ ${ }^{23}$ Faculty of Education UKM, MALAYSIA \\ E-mail: s.khairiah@kqt.edu.my
}

\begin{abstract}
The advances in technology and communication have brought changes in the teaching and learning and daily lives of students both at school and university. Learning in the 21st century has largely used interactive media as an intermediary and a form of channel in the transmission of information. One of the most popular applications in the teaching and learning process is the Telegram application. This app is one of the most popular interactive mediums for educators because of its suitability for sending messages, sharing lecture notes, and being accessible not only via smartphones but also computers without the need for a smartphone connection. The Telegram app also provides an effective means of interaction among students and teachers and helps to accelerate their learning process. This concept paper aims to discuss the application of telegram applications as a teaching and learning platform for History with student performance focused on secondary school students. Telegram applications have many advantages over other applications commonly used in education. One of the benefits is that you can save your shared data without being downloaded directly to your smartphone or computer and share documents in larger sizes up to $1.5 \mathrm{~GB}$. In conclusion, the use of the Telegram app helps students to better understand the learning outcomes and thus improve their learning performance.
\end{abstract}

Keywords: Telegram applications, interactive media, student performance

\section{Introduction}

The world of education is evolving over time as the times and currents of modernity change. Social media has become a medium of use and a guide for teaching and learning with creative and critical thinking. Educators and students need to explore the various techniques and methods of teaching and application in the classroom in order to make the most of their time (Kashful Munirah Yusof \& Anuar Ahmad, 2016). During this millennium, a growing number of sophisticated applications exist and are practiced as telegram applications 
are increasingly being used in education. According to Norhasna Yaakob \& Mohd Jasmy Abd Rahman (2006), the use of applications such as telegram applications can be a good teaching medium to attract students to the teaching and learning process at school or university.

The importance of using social media such as telegram applications is shaping the learning environment of students globally (Nurhuda Ahmad \& Fariza Khalid, 2016). This application is also seen to provide good context and ease in the teaching and learning process (Fatin Fatinah \& Aidah Abdul Karim, 2016). The content of a lesson is very important in understanding a subject that is intended to be presented to the students who are the subject of the discussion and the students need to focus on it so that they are not left out by the teacher. According to Nor'ain Nanyan \& Aidah Abdul Karim (2016) the rapidity of information technology has surpassed the physical space of lecture halls that are globalized and lifelong.

Teaching and learning subject History in schools is often faced with a variety of problems that make students' performance less impressive. According to the results of the 2008 Malaysian Certificate of Education (SPM) examination, student performance in History subjects was inconsistent and obtained a $59.8 \%$ result which proved that History subjects did not perform well compared to other subjects (Rossafri Mohamad \& Shabariah Mohamad Shariff , 2011). This is a major challenge for teachers as it is a core subject in the SPM examination and is also a compulsory subject. Therefore, the teaching and learning methods of discussion using telegram applications need to be implemented more efficiently to activate the learning environment and increase student interest in History subjects thus enhancing student achievement.

\section{Telegram Concepts and Features}

The telegram app introduced on August 14, 2013 has reached the level of iOS and then Android on October 20, 2013. It has reached 100,000 active daily users. In terms of interface, the telegram application has an attractive and orderly look and is similar to the Whatsapp app which has advanced and latest technology elements. Telegram applications is one of the most innovative services as it constantly offers new features that are able to attract users.

According to Zanaton (2017), telegram applications are an innovation in the teaching and learning process that needs to be implemented in education. In addition to solving the problem of student absenteeism, the use of this app can ensure active participation of students in the classroom. In addition, learning to use telegram applications is more flexible for teachers and students based on the feedback received among the various groups. The feedback also shows that the use of telegram applications provides students with a new experience of learning methods that are creative, engaging and spontaneous.

The advent of the latest technology has also increased the use of telegram applications as a communication platform for students to share information, especially in History subjects. Through this medium, teachers can create groups to allow for interaction between teachers and students in a virtual discussion group with faster and easier access. This method is also an easy social network because it provides users with an opportunity for students especially to access the information they need at home and abroad with access to information globally, especially in education (Sayan, 2016).

\section{Telegram Application Implication in Historical Learning}

Telegram applications are meant to share information with students and through this medium, students can share pictures, files, audio, video and more with users and friends. In addition, the app also aims to facilitate and make learning among students more enjoyable. Teachers need to be more creative to produce quality learning content, integrate with other applications, save time and connect more effectively with the teacher-student community. The dynamic of learning becomes more interactive and responsive with the use of telegram applications (Noraya Elya Mohamad et.al., 2016).

The findings of the previous study show that telegram applications can generate student ideas during virtual discussions and assist in students' academic achievement by opening up the idea-sharing space. The effectiveness of teaching and learning techniques using telegram applications was also supported by the students themselves. In a study conducted by Monalisa \& Ardi (2013) stated that virtual learning is an effective moderator in the teaching and learning process thus enhancing students' motivation and understanding.

\section{Improving Student Performance}

The process of teaching and learning History subjects by applying telegrams improves motivation, learning style, comprehension and can overcome the obstacles students face such as information leakage when they are absent from school. Teaching and learning subject History in discussions using telegram applications also 
succeeded in improving the teaching and learning style among teachers and students. These learning styles include group learning (collaborative), two-way interaction and selfdirected learning that ultimately results in effective learning. Martin's (2002) study stated that students' motivation and achievement would be higher if the teaching method was adapted to the mode of learning that students liked.

In addition, discussion methods using telegram applications as well as assistance from other social networking applications enable students to gain a better understanding of their learning. Two-way interaction, collaboration and self-learning can enhance students' understanding of a topic that is often difficult to grasp through conventional teaching methods. This is supported by Windle and Waren (2005) that collaborative learning theory can generate interest and motivation among students. Teachers provide guidance on student engagement in collaborative processes and discussions so as to build an interaction between students to develop a student's thinking skills and to gain an understanding of a concept.

In addition, a study conducted by Syed Lamsah Syed Chear (2017) shows that teaching and learning through telegram applications have the potential to enhance students' ability to master learning outcomes. Students have a positive perspective on virtual learning, but their willingness to engage in this method of teaching depends on the teacher's initiative to guide and the facilities provided. The ability of students to provide quality feedback gives them the hope that learning processes can take place through virtual learning.

Issham et.al. (2016) state that learning based on mobile technology (m-learning) can enhance students' confidence to master their learning objectives. Telegram applications can serve as the best platform for teaching and learning processes that enhance interaction, communication and collaboration, knowledge sharing and are flexible and easy to use (Ashraf \& Kamaljit, 2010). However, it should be noted that the use of Web applications alone does not guarantee students' learning, but it will be beneficial if used with effective methods and strategies and with clear goals.

\section{Proposal}

The education world must modernize by making innovations that are relevant to the challenges of the future. Changes in the teaching and learning process in fact want to improve ways of learning in schools to make students more intelligent, creative, critical and thoughtful in thinking and acting. In this way, students are able to recognize their own level of intellectual and intellectual ability in contemporary and progressive contexts so that they can compete with their peers.
The teaching and learning process based on telegram applications is well implemented in Malaysia, especially in History subjects as it involves many facts about history from within and outside the country. In order for students to experience the fun of learning, the sophisticated and sophisticated research methodology needs to be applied more collectively and in-depth. Education-related training needs to be enhanced in virtual discussions such as this telegram application as it is easy to use anywhere and anytime.

History subjects need to be intensified in the application of telegram applications. During the discussion, students should be more actively involved so that teachers can understand the issues they are facing. Teachers should integrate students who are competitive and passionate about achieving conducive and effective learning. Generic skills also need to be present in every student so that they can remain active in thinking and engaging in education. The makers of the telegram application are also encouraged to enhance the quality of file storage to the extent that students will enjoy downloading the learning notes and reviewing them quickly and effectively and thus engaging in two-way information sharing sessions.

\section{Conclusion}

Overall, telegram applications play an important role in shaping the development of conducive and effective teaching and learning processes, especially in History subjects. This app has features and benefits that students can use to get information quickly, easily and quickly. Its flexible use can be used anywhere and at all times also requires students to access it more often. The discussions triggered in the channel are arguably helpful for students to use the latest technology tools effectively. Previous studies have also shown that the use of an application depends on the way it is used. All parties need to work together to implement the application of telegram applications and to work together to improve the education system around the world.

Telegram applications can be useful applications for learning purposes among students and can enhance student engagement in learning through discussions in this application. Telegram applications as a learning platform History is seen as more practical for learning purposes. This is because in addition to frequently using this application for personal purposes, the individual may also interact with friends or teachers as a scientific discussion of topics learned in the classroom. They can make voice or video calls or attach files for sharing with friends in groups.

The use of telegram applications as a learning platform among students should be emphasized for teachers 
to their students so that teaching and learning activities can be carried out more effectively in and out of the classroom. In addition, the availability of this telegram application allows students and teachers to communicate in cyberspace face-to-face to carry out activities and disseminate information faster regardless of time and place (Oller 2012). As such, it can highlight another medium in the decisionmaking process to improve the delivery of information.

In conclusion, this conceptual paper concludes that using telegram applications as a History learning platform can enhance students' motivation, understanding and performance. This approach is a student-centered teaching and learning process that provides students with opportunities to actively engage in activities and enable social learning to occur through collaborative discussions when dealing with problems or misunderstandings. Furthermore, students' motivation for teaching and learning materials is indirectly generated through the use of this telegram application. Thus, effective learning will take place and will be followed by improved student achievement in History subjects.

\section{References}

[1] Ashraf, D. \& Kamaljit, I. L. (2010). The impact of the new web 2.0 technologies in communication, development and revolutionsof societies. Journal of Advances in Information Technology. 2(4) : 204216.

[2] Aziz, N. A. A., \& Ahmed, M. T. (2017). EPembelajaran dalam Pengajaran dan Pembelajaran Bahasa Melayu di IPG Kampus Ipoh. Jurnal Penyelidikan Dedikasi, 11.

[3] Chear, S. L. S. (2017). Pengajaran dan Pembelajaran Melalui Aplikasi Whatsapp dan Telegram di Universiti Swasta. Jurnal Pendidikan Malaysia, 2(42), 1-14.

[4] Deo, S. \& Hassan, S. 2014. Exploitation of online social networks (OSNs) among university student : A case study of the University of Dodoma. Inetrnational Journal of Computer Applications, 94(12) : 10-14.

[5] Devita Anggraini, S. \& Chendra Wibawa, S. (2019). Pengembangan Media Pembelajaran Berbasis Telegram pada Mata Pelajaran Teknik Pengolahan Video Untuk Meningkatkan Kemampuan Berfikir Kognitif Siswa. It-Edu, 3(20).

[6] Fatin Fatinah Manap \& Aidah Abdul Karim. (2016). Pemilihan dan Penggunaan Media Sosial dalam Proses Pengajaran dan Pembelajaran (P\&P) : Satu Kajian di KIS. Universiti Kebangsaan Malaysia. 1(36-40).
[7] Hasan, S. H. (2019). Pendidikan Sejarah Untuk Kehidupan Abad Ke 21. Historia : Jurnal Pendidik dan Penelti Sejarah, 2(2), 61-72.

[8] Issham Ismail, Siti Norbaya Azizan \& Thenmolli Gunasegaran. (2016). Mobile learning in Malaysian universities : Are students ready? International Journal of Interactive Mobile Learning. 10(3) : 1723.

[9] Kashful Munirah Yusof \& Anuar Ahmad. (2016). Media Sosial dalam Pengajaran dan Pembelajaran Sejarah Sekolah Rendah. Universiti Kebangsaan Malaysia. 1(1-15).

[10] Kwartolo, Y. (2010). Teknologi informasi dan komunikasi dalam proses pembelajaran. Jurnal Pendidikan Penabur, 14, 15-43.

[11] Malik, A., Siraj, S., Abdullah, M. R. T. L., \& Sakika, K. A. (2017). Keperluan Dan Penerimaan Guru Pelatih Terhadap Pelaksanaan $M$ Pembelajaran Dalam Pendidikan Guru. JuKu: Jurnal Kurikulum \& Pengajaran Asia Pasifik, 5(3), 62-70.

[12] Miasan, N. A., \& Kasim, T. S. A. T. (2018). Pengamalan M-Pembelajaran Dalam Kalangan Guru Novis Pendidikan Islam Di Sabah. Journal of Islamic Educational Research, 3(1), 11-20.

[13] Monalisa, M., \& Ardi, H. (2013). Using "Edmodo" educational social network in teaching English for high school students. Journal of Ennglish Language Teaching. 1(119-120).

[14] Nair, S. (2005). Penggunaan model konstruktivisme lima fasa needham dalam pembelajaran sejarah. Malaysian Journal of Educators and Education, 20, 21-41.

[15] Nor'ain Nanyam \& Aidah Abdul Karim. (2016). Penerimaan Penggunaan Media Sosial dalam Pembelajaran di Kalangan Pelajar Fakulti Pendidikan Kolej Universiti Islam Antarabangsa Selangor (KUIS). Universiti Kebangsaan Malaysia. 1(60-62).

[16] Noraya Elya Mohamad, Aidah Abdul Karim \& Md Yusoff Daud. (2017). Penggunaan FROG VLE Sebagai Sistem Pengurusan Pembelajaran (LMS) Di Sekolah Seluruh Malaysia. Universiti Kebangsaan Malaysia. 1(37).

[17] Norhasna Yaakob \& Mohd Jasmy Abd Rahman. (2016). Perspeksi Guru Terhadap Penggunaan Media Sosial dalam Pengajaran dan Pembelajaran : Satu Tinjauan di Sekolah Kebangsaan Ledang. Universiti Kebangsaan Malaysia. 1(12-17).

[18] Nurhuda Ahmad \& Fariza Khalid. (2016). Penggunaan Media Sosial di Kalangan Guru Perpustakaan dan Media (GPM) : Satu Kajian Kes 
di Zon Cheras, Hulu Langat. Universiti Kebangsaan Malaysia. 1(27-29).

[19] Oller, R. 2012. The Future of Mobile Learning. EDUCOUSE centre for Applied Research.

[20] Putra, I. E. (2014). Teknologi media pembelajaran sejarah melalui pemanfaatan multimedia animasi interaktif. Jurnal TeknoIf, 1(2).

[21] Rahayu, W. (2019). Pembelajaran Sejarah untuk Generasi Z. Jurnal Pendidikan Sejarah Indonesia, 2(1), 1-7.

[22] Rossafri Mohamad \& Shabariah Mohamad Shariff. (2011). Kesan Penggunaan Laman Sosial ke atas Kaedah Perbincangan di dalam Pengajaran dan Pembelajaran Mata Pelajaran Sejarah. Jurnal Teknologi Pendidikan Malaysia, 1(1).

[23] Qamar, K., \& Riyadi, S. (2018). Efektivitas Blended Learning Menggunakan Aplikasi Telegram. AtTajdid: Jurnal Ilmu Tarbiyah, 7(1), 1-15.

[24] Saleh, M. P., \& Siraj, S. (2017). Analisis Keperluan Pembangunan Model Pengajaran M-Pembelajaran Mata Pelajaran Sejarah Sekolah Menengah. JuKu: Jurnal Kurikulum \& Pengajaran Asia Pasifik, 4(4), 12-24.

[25] Saputro, D. A. (2018). Pengembangan Bahan Ajar Pembelajaran Berbasis E-Learning dengan Menggunakan Aplikasi Telegram pada Matapelajaran Sejarah di SMA Negeri 1 Kauman tulungagung. SKRIPSI Jurusan Sejarah-Fakultas Ilmu Sosial UM.

[26] Suryadi, A. (2007). Pemanfaatan ICT dalam pembelajaran. Jurnal Pendidikan Terbuka dan Jarak Jauh, 8(3), 83-96.

[27] T. H Brown. (2005). Towards a model for $m$ learning in Africa. International Journal on Elearning, 4(3), 399-315.

[28] Yusof, M. N. M., \& Tahir, Z. (2017). Kepentingan Penggunaan Media Sosial Teknologi Maklumat Dalam Pendidikan Ipta. e-BANGI, 12(3), 1-10.

[29]Zanaton H. Iksan \& Sumaiyah Mohd Saufian. (2017). Mobile Learning : Innovation In Teaching And Learning Using Telegram. Malaysia : Universiti Kebangsaan Malaysia. 